authentic gophersite only on virgin prairie by a roadside, misjudged time to move when a car came along, and so died out.

It was on such close-nibbled gopher mounds, warm and dry to lie upon on spring days, that we found the first furry crocus buds; a stone turned over would discover to us a world of ants or beetles; or, arm raised against the sun, we would watch the slowly swirling flocks of cranes and listen to their ventriloquistic cronkings.

I cannot remember antelope, but they were there till the winter of disastrous blizzard, 1906-7. We often saw slinking coyotes and heard their wierd keening in the night. I, it was, who saw the fox, and was as proud that Dad trusted my description as I was of my first "first sight" record; but that "first sight" has left till now the authentic glow of spirit which the amateur naturalist counts as full reward!

About that time, they tell me, I also proved one spring that I had seen the first hawk. I hotly denied it was a crow! Its wings went thus ... and I beat my arms lazily, then tilted and swayed them as though soaring. The point was conceded.

Gophers we snared, trapped, shot or pcisoned, they were so destructive of the precious sprouts of grain; but we never could keep wild things as pets lest their natural wit be dulled by trust and easy living, dice loaded against them when turned loose to contend with normal hardship and foes again.

Through those years I craved a book such as the Field Guides we have now, to tell me the name of the wee sparrow nesting in a mossy cup by a slough where a cow had stepped in wet weather, or the difference between a blackbird with red epaulets and the one with white on the wings.

Such a book I never found till, as a teacher, I moved to this poplar dotted country east of Moose Mountains. Here I first knew wild fruit other than strawberries, met our lily emblem in abundance, was charmed by the gold-kid slippers of our wild orchid, the flash of gaudy orioles through the trees and learned songs of vireo and warbler.
Other woodpeckers than the flicker that followed telephone lines across the prairie tap on my trees. Great blue herons fish the Antler Creek, and we are apt to see a porcupine lumbering among the willows. White tailed deer are common and beavers in a few years have reached pest proportion. While plain birds such as the lark bunting (of the white epaulet) have vacated our bluffy terrain the chickadee has become a familiar sprite. Yet fifty years ago this country was still burnt clean as any western plain, with "not even a sapling big enough for a whip" as one pioneer assured me.

Nature has proven that though drought came, there have been years of excessive rainfall and deep sloughs since. The sweep of devastating fires retired into past history with cultivation of the land. Wildlife populations have changed with the increase of parkland habitat and the use of land by man. It is all part of the inevitable change due to civilization.

We may deplore the loss of natural growth in our home acres. All we can do is, each of us, to refrain from destroying it further on untilled land. We should remember the pioneer adage, "a penny saved is a penny gained." That is the only way we can keep enough "seed," be it bird or beast or flower, to assure that future generations of our children will know the Saskatchewan, even a little, to which we came.

\section{Winter Birds at Nipawin}

Anne Matthews of Nipawin reports a good winter for birds, with Redpolls and Evening Grosbeaks especially numerous at the banding station, and lots of Ravens about. Her brother banded over 800 Redpolls and 67 Evening Grosbeaks this winter. $\mathrm{He}$ caught one Evening Grosbeak that had been banded at Marquette, Michigan, and another that had been banded at Madison, Wisconsin.

One short-eared Owl was seen by the Matthews February 13, and 4 more a few days later by Maurice Street. This posed the question of whether the owls were migrating very early or had stayed all winter to feed on the hundreds of mice. 